\title{
Use of diatomite and pumice as stabilizers in stone mastic asphalt mixtures
}

\section{Uso de diatomita y piedra pómez como estabilizadores en mezclas asfálticas de masilla de piedra}

Şevket Aslan (Main and Corresponding Author)

Department of Civil Engineering, Faculty of Engineering, Erciyes University

38039 Melikgazi, Kayseri (Turkey)

sevketaslan@erciyes.edu.tr

\section{Bekir Aktaş}

Department of Civil Engineering, Faculty of Engineering, Erciyes University

38039 Melikgazi, Kayseri (Turkey)

baktas@erciyes.edu.tr

Manuscript Code: 1137

Date of Acceptance/Reception: 29.11.2018/14.06.2018

DOI: 10.7764/RDLC.17.3.531

\begin{abstract}
Stone Mastic Asphalt (SMA) mixtures are susceptible to drain down since they contain more bitumen comparing to Hot Mix Asphalt (HMA) mixtures. To prevent this problem, stabilizers are used in SMA mixtures. Stabilizers are costly materials and needed to be manufactured with several processes. In this study, pumice and diatomite materials were evaluated to see whether they could be used in SMA mixtures as stabilizers. The optimum bitumen contents of the mixtures having different amounts of pumice $(1,1.5$ and $2 \%)$ and diatomite $(0.25,0.50,0.75$ and $1.00 \%)$ were determined in accordance with Marshall design method. Then, the drain down characteristics of SMA mixtures at optimum bitumen content were found. Finally, the resistance of the mixtures to moisture-induced damage is analyzed by conducting the Tensile Strength Ratio (TSR) test. The results indicate that there is a high potential of using certain amounts of pumice and diatomite in SMA mixtures as stabilizers.
\end{abstract}

Keywords: Stone mastic asphalt, stabilizer, diatomite, pumice, fiber.

\section{Resumen}

Las mezclas de Masilla de Piedra de Asfalto (SMA) son susceptibles de drenar hacia abajo ya que contienen más betún en comparación con las mezclas de Mezcla Caliente de Asfalto (HMA). Para evitar este problema, se utilizan estabilizadores en mezclas de SMA. Los estabilizadores son materiales costosos y necesitan ser fabricados con varios procesos. En este estudio, se evaluaron los materiales de piedra pómez y diatomita para ver si se podían usar en mezclas de SMA como estabilizantes. Los contenidos óptimos de betún de las mezclas que tienen diferentes cantidades de piedra pómez (1, 1.5 y $2 \%)$ y diatomita $(0.25,0.50,0.75$ y $1.00 \%)$ se determinaron de acuerdo con el método de diseño Marshall. Luego, se encontraron las características de drenaje de las mezclas de SMA con un contenido óptimo de bitumen. Finalmente, la resistencia de las mezclas al daño inducido por la humedad se analiza mediante la prueba de relación de resistencia a la tracción (TSR). Los resultados indican que existe un alto potencial de usar cierta cantidad de piedra pómez y diatomita en mezclas de SMA como estabilizantes.

Palabras clave: Masilla de piedra de asfalto, estabilizador, diatomita, piedra pómez, fibra.

Introduction

One of the most significant materials universally used for pavement of roads is asphalt concrete. The research studies and engineers have been evaluating the development of asphalt pavements regularly. Strength against cracking, creep, fatigue, skid and water resistance are the fundamental characteristics that roads produced with asphalt concrete should have (Huang, 2003).

Environmental concern in the society is rising. Using new materials obtained from urban, agricultural, and industrial wastes is being investigated by the research studies and governmental institutions in order to see their possible use in the industrial and engineering applications (Pourtahmasb \& Karim, 2014). The objective of these type of aims is to decrease the amount of excess material in landfills and to lower the total cost of engineering products (Herráiz, Herráiz, Domingo, \& Domingo, 2016).

Vega-Zamanillo, Calzada-Pérez, Lastra-González, Indacoechea-Vega, \& Fernández Ortega (2017) investigated the use of cupola furnace slags, green sand and reclaimed asphalt pavement in low traffic intensity roads. Using Marshall Method, the mix design and voids percentage of the mixtures were determined. The performance of the mixtures was evaluated considering water sensitivity and wheel tracking tests. The study proved that cupola furnace slags, green sand and reclaimed asphalt pavement can be used the roads with low traffic as binder course. 
In addition to using waste materials, researchers and engineers in the last decades have focused on replacing the synthetic components in the asphalt mixtures with the materials from the nature. One of the synthetic components in the asphalt mixtures to which research studies and engineers have paid more attention to is fiber. The reason of this action is the conventional fibers are too costly. This results in a higher total cost of asphalt mixtures (Oda, Leomar Fernandes, \& Ildefonso, 2012). There are several studies indicating a comparison between mixtures of standard fibers and mixtures of natural stabilizers.

Oda et al. (2012) added natural fibers (sisal and coconut) to stone mastic asphalt (SMA) mixtures. Mixtures with sisal and coconut fibers resulted in a higher resistance comparing with the standard fibers (cellulose and polyester). Moreover, the natural fibers prevented the bitumen or bitumen/filler from draining down. Sharma and Goyal (2006) studied the use of crumb rubber modified bitumen. They conducted laboratory experiments on stone mastic asphalt (SMA) mixtures produced with crumb rubber modified bitumen and natural fibers. The study revealed that SMA mixtures with crumb rubber modified bitumen have better characteristics of resistance to moisture, resistance to permeability, indirect tensile strength (ITS) values, retained stability values, rutting performance, resistance to creep and aging than SMA mixtures with fibers as stabilizers.

Putman \& Amirkhanian (2004) investigated different types of fibers: cellulose, tire, carpet and polyester. The results of the study demonstrated that permanent deformation and moisture susceptibility have no crucial difference when waste fibers, cellulose or polyester fibers are compared. Moreover, the toughness of the mixtures is developed with the addition of tire, carpet and polyester fibers when it is compared to the mixtures with cellulose fibers.

Arshad, Mansor, Shafie, \& Hashim (2016) evaluated the performance of Kenaf (natural fiber) in stone mastic asphalt (SMA) mixtures to examine the drainage of bitumen. Kenaf compared with synthetic fiber (Viatop ${ }^{\circledR} 66$ ) resulted in a better performance in terms of rut depth. In addition, the optimum bitumen content ratio is lower for the mixtures with Kenaf. The study suggests that synthetic fiber could be replaced by the natural fiber of Kenaf for SMA14 mixture.

Kofteci (2018) investigated the use of pumice as mineral fiber in Stone Mastic Asphalt (SMA) binder course. The results of Schellenberger test, wire basket test and water sensitivity test proved that an appropriate proportion of $4 \%$ of pumice is an alternative to cellulose fibers.

Atasaral, Gungor, Orhan, Kasak, \& Cubuk (2008) studied the effect of diatomite on the performance of SMA mixtures. The mixture produced with the conventional fiber was compared to the mixtures having different amounts of diatomite $(3 \%, 4 \%, 5 \%)$. Rutting test, fatigue life test and indirect tensile test were conducted on the samples. The results indicated that the mixtures show approximately similar behaviors in terms of water damages, tensile strength and resistance to rutting. However, the SMA mixtures produced with fiber have a better performance under fatigue life test.

In this study, pumice and diatomite materials were used as stabilizers to be studied in SMA by conducting a series of laboratory experiments. The performance of the mixtures with pumice and diatomite was compared to the conventional fiber used commonly in the engineering applications. Marshall mix design method was applied to be able to determine the optimum bitumen content of the different type of the mixtures. The results of Marshall Stability, voids filled with asphalt $\left(V_{f}\right)$, voids in mineral aggregates $(V M A)$, bulk specific gravity $\left(D_{p}\right)$ and flow were obtained. By following the procedures of the Schellenberger drain down test, the drain down values were determined for the mixtures at optimum bitumen contents. The resistance of the mixtures to moisture-induced damage was examined for the mixtures satisfying the drain down specification limit. Furthermore, the Brunauer-Emmett-Teller (BET) surface areas of pumice, diatomite and fiber materials were determined. Additionally, Scanning Electron Microscope (SEM) was performed to interpret the surface texture of pumice, diatomite and fiber. Moreover, chemical compositions of the pumice, diatomite and fiber have been revealed by X-Ray Fluorescence (XRF) method.

Methodology

\section{Pumice and diatomite}

As stabilizers for SMA, pumice and diatomite were used for the replacement of fiber (Viatop ${ }^{\circledR 66}$ ). In the conventional SMA mix design, fibers as stabilizers are used to prevent the bitumen from flowing downward through the mixture. In contrary to fiber, pumice and diatomite are natural products. They can be directly used after a minor process of crushing, grinding and sieving. This makes it possible for the pumice and diatomite to be considered in the use of asphalt mixtures. 
Pumice and diatomite materials are very soft and they can be easily grinded by hand. For this reason, pumice and diatomite materials passing No.200 sieve were added to the SMA mixtures. In Figure 1 and Figure 2, appearances of pumice and diatomite are given respectively (Aslan, 2015).
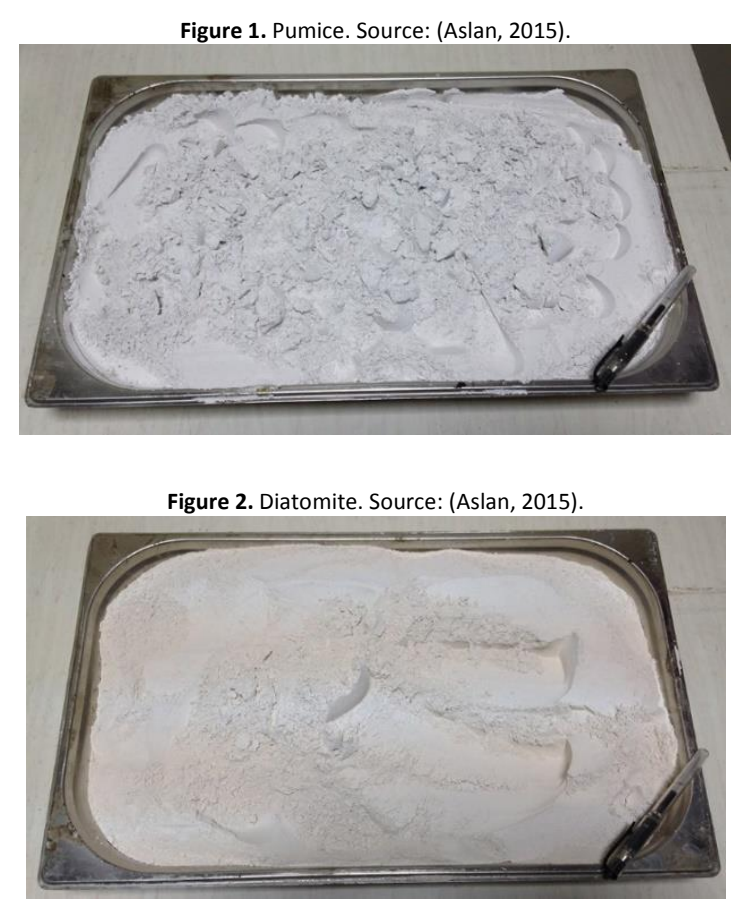

In order to indicate the surface texture of pumice, diatomite and fiber, Scanning Electron Microscope (SEM) was performed. The SEM images of pumice, diatomite and fiber are seen in Figure 3, 4 and 5, respectively. Considering the captured SEM images, it can be said that pumice and diatomite have similar surface textures comparing to that of fiber. This observation proves that pumice and diatomite are also able to prevent the bitumen from flowing, as well as fiber (Viatop ${ }^{\circledR 66)}$. Moreover, X-Ray Fluorescence (XRF) method have been conducted in order to reveal the chemical compositions of pumice, diatomite and fiber. These materials mainly consist of $\mathrm{SiO}_{2}, \mathrm{Al}_{2} \mathrm{O}_{3}, \mathrm{CaO}$ and $\mathrm{K}_{2} \mathrm{O}$. The ratio of compositions of pumice, diatomite and fiber has been demonstrated in Table 1.

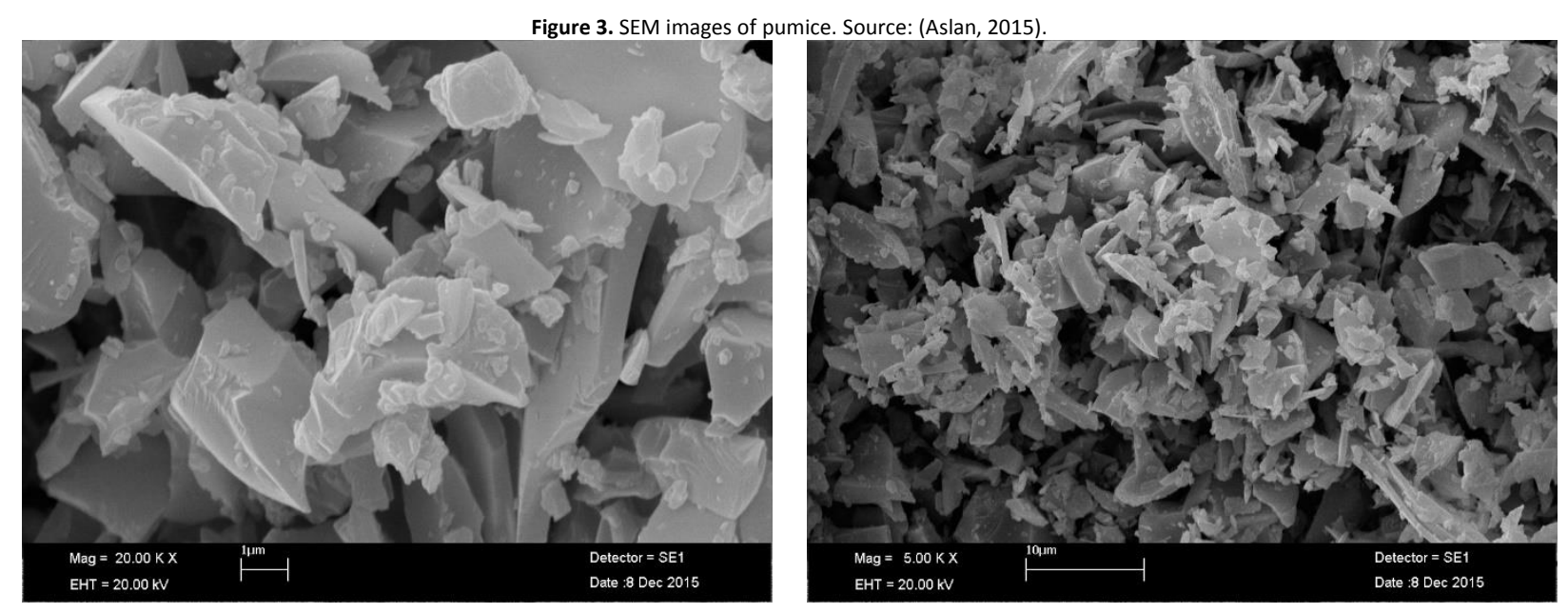



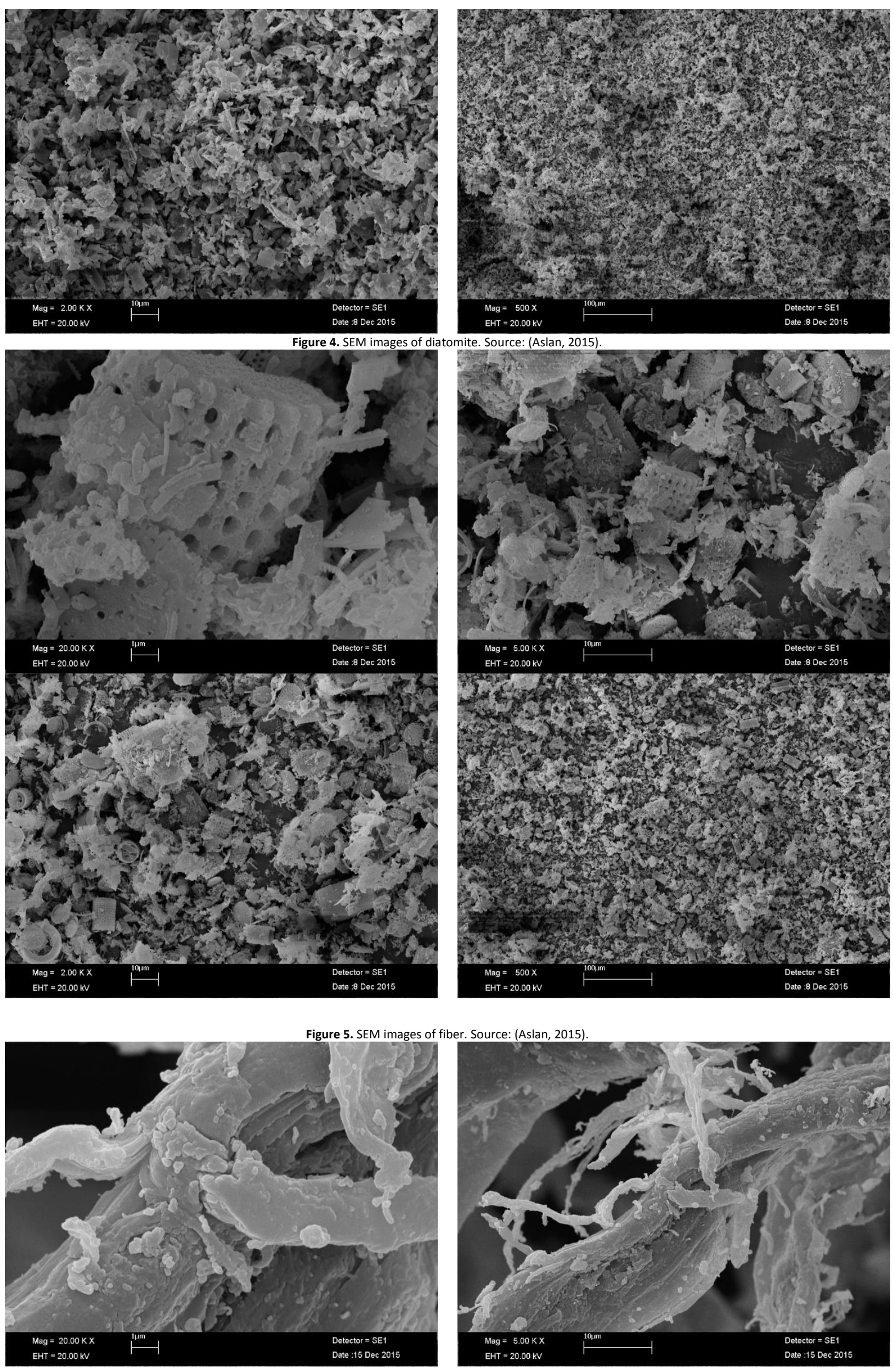

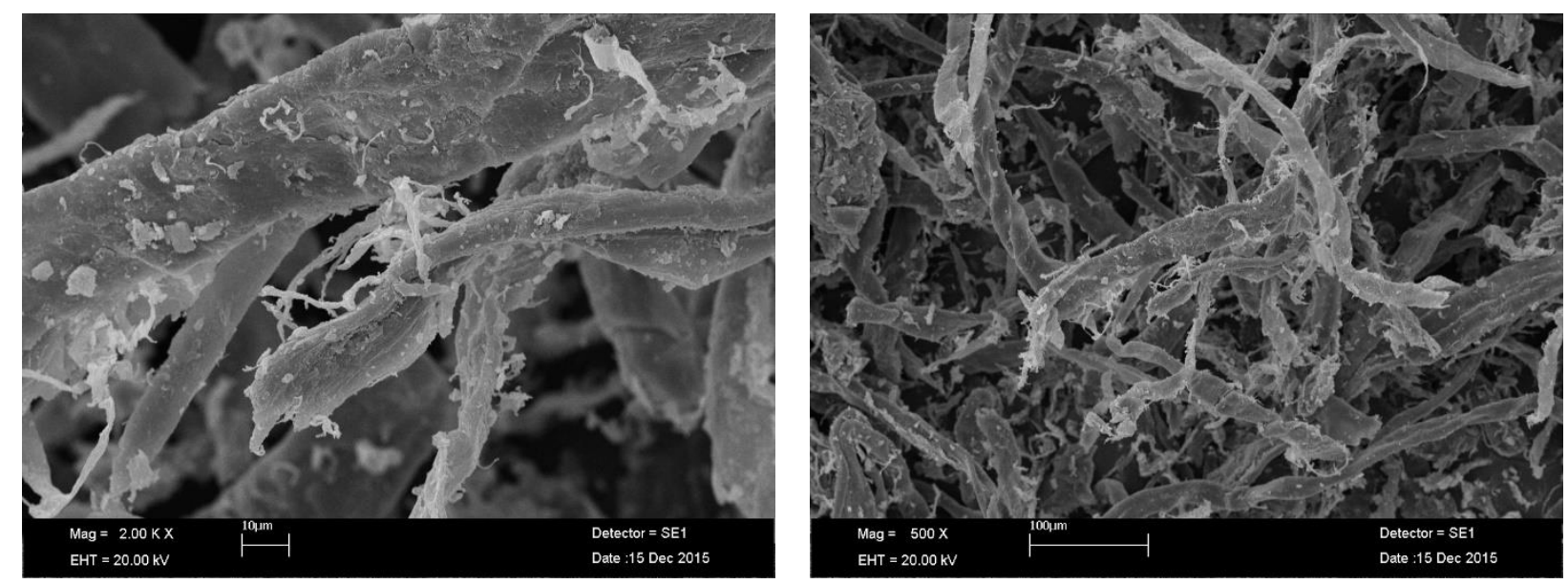

Table 1. Chemical compositions of pumice, diatomite and fiber. Source: (Aslan, 2015).

\begin{tabular}{lccc}
\hline & \multicolumn{3}{c}{ General composition (\%) } \\
\cline { 2 - 4 } Compounds & Pumice & Diatomite & Fiber \\
\hline $\mathrm{SiO}_{2}$ & 72.50 & 69.38 & 9.38 \\
$\mathrm{Fe}_{2} \mathrm{O}_{3}$ & 1.24 & 2.48 & 3.54 \\
$\mathrm{Al}_{2} \mathrm{O}_{3}$ & 12.62 & 4.65 & 5.45 \\
$\mathrm{CaO}$ & 0.86 & 4.39 & 36.83 \\
$\mathrm{MgO}$ & 0.11 & 1.0 & 1.57 \\
$\mathrm{Na}_{2} \mathrm{O}$ & 3.53 & 0.39 & 2.07 \\
$\mathrm{~K}_{2} \mathrm{O}$ & 4.06 & 0.24 & 0.52 \\
$\mathrm{SO}_{3}$ & 0.08 & 0.07 & 15.78 \\
$\mathrm{Cl}_{\mathrm{TiO}}$ & 0.12 & - & 0.44 \\
$\mathrm{P}_{2} \mathrm{O}_{5}$ & 0.08 & 0.24 & 0.85 \\
$\mathrm{MnO}_{n}$ & 0.06 & 0.71 & 0.27 \\
\hline
\end{tabular}

In addition, The Brunauer-Emmett-Teller (BET) surface areas of the materials have been calculated. Also, pore size and pore volume characteristics were determined. BET surface area, pore size and pore volume features are seen in Table 2.

\begin{tabular}{lccc}
\hline \multicolumn{4}{c}{ Table 2. BET Analysis. Source: (Aslan, 2015). } \\
\hline & Fiber & Pumice & Diatomite \\
\hline BET Surface Area $\left(\mathrm{m}^{2} / \mathrm{g}\right)$ & 0.14 & 1.37 & 22.55 \\
Pore Volume $(\AA)$ & 0.001 & 0.007 & 0.081 \\
Pore Size $(\AA)$ & 319.44 & 214.59 & 144.01 \\
\hline
\end{tabular}

\section{Mineral aggregates}

Basalt aggregates used in this study were received from Tuzhisar quarry, Kayseri, Turkey. The fractions of basalt mineral aggregates were $0 / 5 \mathrm{~mm}$ and $5 / 13 \mathrm{~mm}$. As a filler, limestone was used due to the less production of filler material in basalt quarry. Properties of basalt and limestone aggregates are shown in Table 3.

\section{Experimental Program}

First of all, in order to evaluate the possible usage of pumice and diatomite as stabilizers, different amounts were added to the SMA mixtures. The three percentages by mass of pumice (1.0, 1.5 and $2 \%$ ) and four percentages by mass of diatomite $(0.25,0.50,0.75$ and $1.00 \%)$ were used in the mixtures as stabilizers instead of conventional fiber. To determine the optimum bitumen ratio, Marshall mix design method was performed. For this reason, 18 specimens having different bitumen ratios $(6.0,6.5,7.0,7.5,8.0$ and $8.5 \%$ of dry aggregates) were produced for each ratio of pumice and diatomite. After the production, Marshall stability and flow values were determined. 
Table 3. Physical properties of aggregates. Source: (Aslan, 2015)

\begin{tabular}{|c|c|c|c|c|c|}
\hline Test & Requirements & $\begin{array}{l}\text { Filler (Passing } \\
\text { No:200 Sieve) } \\
\end{array}$ & Fine & Coarse & Standard \\
\hline $\begin{array}{l}\text { Flakiness Index } \\
\text { (\%) }\end{array}$ & $<35$ & & & 13.9 & $\begin{array}{c}\text { ASTM D } 4791 \text { (ASTM D } \\
4791,2010)\end{array}$ \\
\hline $\begin{array}{l}\text { Bulk Specific } \\
\text { Gravity }\left(\mathrm{g} / \mathrm{cm}^{3}\right)\end{array}$ & & 2.750 & 2.690 & 2.820 & $\begin{array}{c}\text { ASTM D } 854 \text { (ASTM D } \\
854-14,2014)\end{array}$ \\
\hline Absorption (\%) & & & 1.79 & 1.16 & $\begin{array}{c}\text { ASTM D } 854 \text { (ASTM D } \\
854-14,2014)\end{array}$ \\
\hline Los Angeles & $\leq 25$ & & & 13.66 & ASTM C 131 (ASTM \\
\hline $\begin{array}{l}\text { Abrasion Test } \\
\text { (\%) }\end{array}$ & & & & & C131/C131M-14, 2006) \\
\hline $\begin{array}{l}\mathrm{Na}_{2} \mathrm{SO}_{4} \text { Sulfate } \\
\text { Soundness Test } \\
\text { (\%) }\end{array}$ & $\leq 14$ & & & 0.02 & $\begin{array}{l}\text { ASTM C - } 88 \text { (ASTM } \\
\text { C88/C88M-18, 2018) }\end{array}$ \\
\hline
\end{tabular}

Secondly, after finding the optimum bitumen content for each type of mixtures, drain down test was conducted. In this test, it was possible to see the effects on the bitumen flow with pumice and diatomite additions.

Finally, to figure out the moisture resistance of the Marshall specimens, Tensile Strength Ratio (TSR) test was performed. In this experiment, the freeze-thaw cycle is applied to a group of three specimens; while, the other three specimens are unconditioned. After the cycle, the indirect tensile strength ratios were compared to see whether they satisfy the minimum specification ratio of $80 \%$ (AASHTO T283-07, 2007). For different types of mixtures, asphalt mixture codes have been assigned as seen in Table 4.

\begin{tabular}{lc}
\multicolumn{2}{l}{ Table 4. Specimen Codes of SMA Mixtures. Source: Aslan (2015). } \\
\hline Specimen \\
Codes & Explanation \\
\hline CS & $0.35 \%$ Fiber (Control Samples) \\
P100 & $1.00 \%$ Pumice \\
P150 & $1.50 \%$ Pumice \\
P200 & $2.00 \%$ Pumice \\
D25 & $0.25 \%$ Diatomite \\
D50 & $0.50 \%$ Diatomite \\
D75 & $0.75 \%$ Diatomite \\
D100 & $1.00 \%$ Diatomite \\
\hline
\end{tabular}

\section{Mix Design}

To produce the Marshall specimens, aggregates, bitumen and stabilizers were mixed in the mixing temperature of 150 ${ }^{\circ} \mathrm{C}$. The penetration grade of the pure bitumen used in this study was $50-70$. The bulk specific gravity of the bitumen was $1.024 \mathrm{~g} / \mathrm{cm}^{3}$, having a penetration value of $55\left(25^{\circ} \mathrm{C}, 100 \mathrm{~g}, 5 \mathrm{~s}\right)$.

The upper and lower limits for SMA Type II aggregate gradations of Turkish General Directorate of Highways were considered in determining the aggregate gradation. To develop a better aggregate gradation, Bailey method was used. By using this method, it was possible to establish a proper structure of the aggregates. The Bailey parameters and gradation curve are shown in Table 5 and Figure 6 respectively. Marshall specimens consisted of 1140-g dry aggregates. The specimens compacted at $140{ }^{\circ} \mathrm{C}$ with 50 blows on each side.

\begin{tabular}{lcc}
\multicolumn{3}{c}{ Table 5. Bailey Parameters of the SMA mixtures. Source: Aslan (2015). } \\
\hline Bailey & & \\
Parameters & Calculated Values & Upper and Lower Limits \\
\hline CA Ratio & 0.17 & $0.15-0.30$ \\
FA $A_{c}$ Ratio & 0.60 & $0.60-0.85$ \\
FA $_{f}$ Ratio & 0.83 & $0.60-0.85$ \\
\hline
\end{tabular}




\section{Marshall Stability Test}

Marshall mix design procedure was used in producing the specimens. The diameter of the molds was $10.16 \mathrm{~cm}$ and the height of the specimens was around $63.5 \mathrm{~mm}$. Samples were mixed at $150{ }^{\circ} \mathrm{C}$ and compacted at $140{ }^{\circ} \mathrm{C}$. 50 blows were applied on each side with $4.5 \mathrm{~kg}$ hummer, which is released at a height of $45 \mathrm{~cm}$.

8 different combinations having the same coarse, fine and filler size aggregates were prepared with various amounts of pumice $(1.0,1.5$ and $2.0 \%)$, diatomite $(0.25,0.50,0.75$ and $1.00 \%)$ and fiber $(0.35 \%)$. Optimum bitumen contents for all of the 8 combinations were found by considering that the air void ratio of $3 \%$ which is the median value of $2 \%$ and $4 \%$, upper and lower limits for SMA according to the specification (Turkey General Directorate of Highways, 2013).

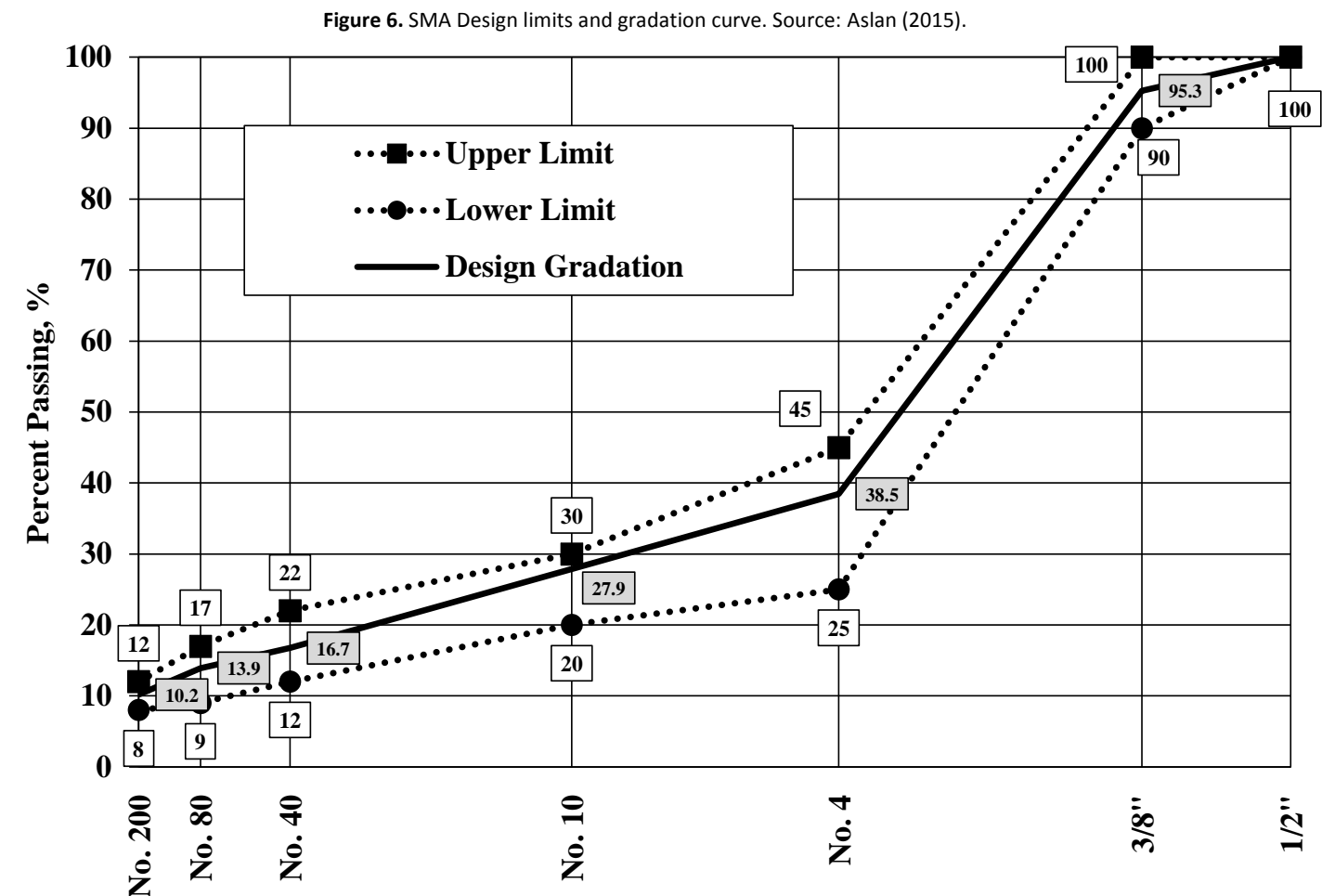

Sieves (Raised 0.45 Power)

Results and discussion

In this section, the results of the Marshall Test, drain down test and resistance to moisture-induced damage are given.

\section{Marshall Test Results}

The results obtained from Marshall Test procedure, optimum bitumen contents, bulk specific gravities, VFA, VMA, stability and flow graphs for all mixtures are demonstrated in Figure 7.

Figure 7 indicates the optimum bitumen contents of SMA samples with different amount of pumice and diatomite. As it is seen in Figure 7, the optimum bitumen ratios increase as the amount of pumice and diatomite increases. The reason of the increase is that the pumice and diatomite absorb more bitumen as they become more in the mixture. The Bulk Specific Gravity values $\left(D_{p}\right)$ get smaller as the amount of pumice and diatomite increases. The reason is the pumice and diatomite materials have less density comparing to the mixture. Voids Filled with Asphalt $\left(V_{f}\right)$ values increase as the amount of pumice and diatomite increases. It can be revealed that as the bitumen content becomes more in the mixtures, then the $V_{f}$ ratio also increases. Voids in Mineral Aggregates (VMA) ratios of the samples get higher due to the addition of the pumice and diatomite materials. All of the mixtures satisfy the minimum VMA limit of $17.0 \%$ except for D25. It can be seen that the stability values of the samples decrease as the pumice and diatomite materials are added. When it comes to flow values, it can be observed that the increase in the amount of pumice and diatomite results in an 
Figure 7. Optimum Bitumen Ratio, Dp, Vf, VMA, Stability and Flow results of the SMA mixtures. Source: Aslan (2015).
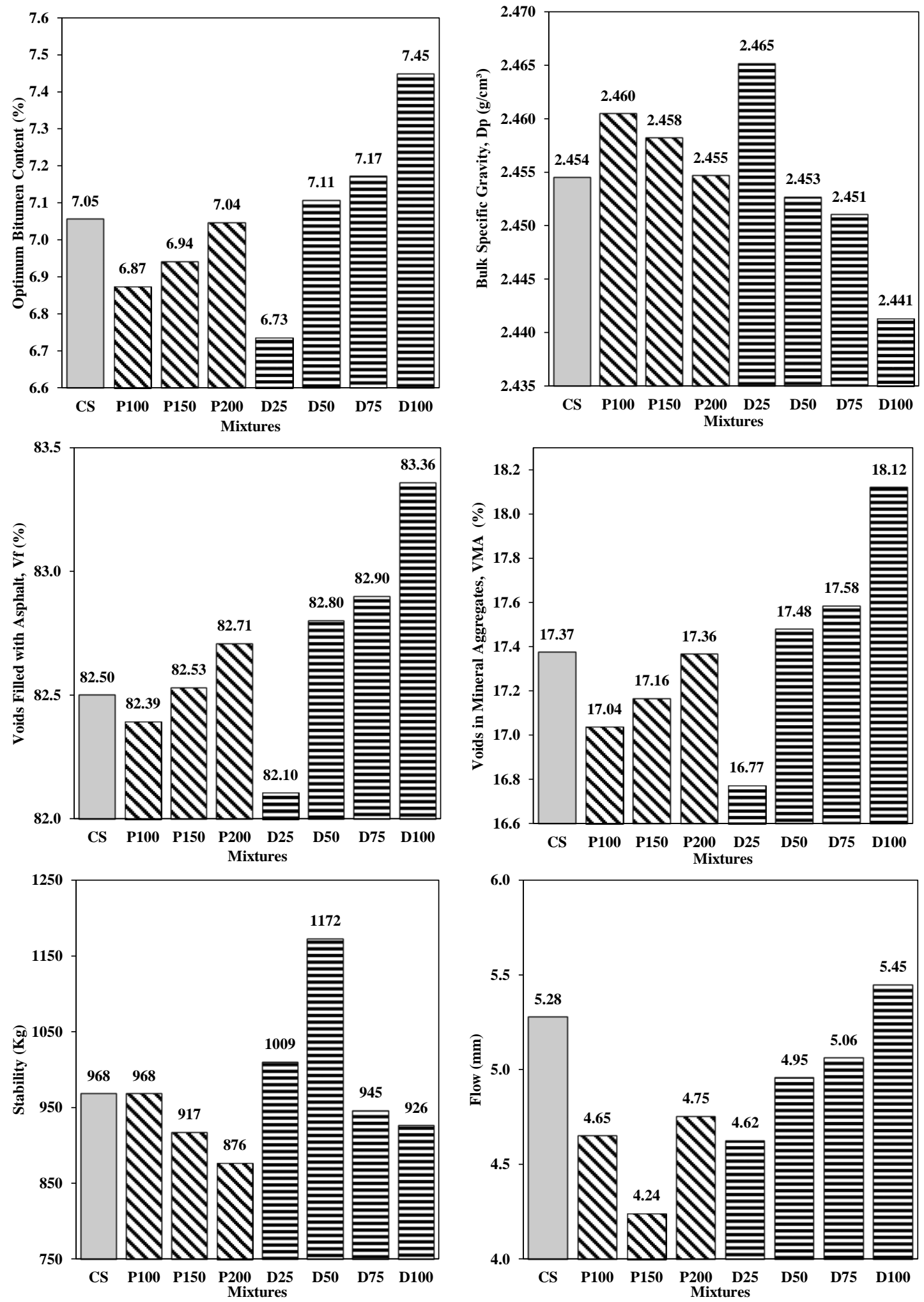

increase in the flow values. Considering all of the flow values of the mixtures, it can be observed that the only mixture having more flow value than the control sample is the mixture of D100. The reason is that the mixture of D100 has a relatively higher optimum bitumen content. The high bitumen percentage of D100 causes aggregates to float in the mixture. Moreover, the homogeneous structure of the mixture is changed by the excess amount of bitumen. For this reason, the mixture of D100 has more flow value than the control sample. 


\section{Drain Down Test Results}

In SMA mixtures, the bitumen content is higher than the other types of Hot Mix Asphalt (HMA) mixtures. The high ratio of bitumen causes a draining problem. During the shipment, storage and placement, some part of the SMA mixtures (bitumen or bitumen/filler) separates itself from the mixture. To prevent this separation, which is called drain down, usage of a stabilizer is needed. In this study, after finding the optimum bitumen ratios of the mixtures by Marshall design method, Schellenberger drain down test was conducted in order to check if the drain down ratios of the mixtures are below the upper limit of $0.3 \%$.

To conduct Schellenberger drain down test (British Standards Institution, 2017), uncompacted $1000 \mathrm{~g}$ of SMA mixture is placed in the oven and heated up to $175^{\circ} \mathrm{C}$ in a $1000 \mathrm{~mL}$ glass beaker. After one hour, the bitumen or bitumen/filler drains down and sticks to the inner side of the glass beaker. The ratio of the amount of drain down to the mixture is called Schellenberger drain down ratio. Figure 8 shows the drain down values of the mixtures of this study. As it is seen in Figure 8, P100 and D25 mixtures have drain down ratios of $0.34 \%$ and 0.35 respectively. These values are higher than the upper limit of $0.3 \%$. This is the reason why the productions with P100 and D25 mixtures are not appropriate. For this reason, the amount of pumice and diatomite must be increased to make drain down ratios less than the upper limit. All of the other types of mixtures (P150, P200, D50, D75 and D100) provide acceptable drain down ratios since the Schellenberger drain down ratios of these mixtures are below the upper limit of $0.3 \%$. The reason is that, by absorption, the additional amounts of pumice and diatomite prevent the bitumen or bitumen/filler from draining down. However, P150 and D50 mixtures are selected since they have less optimum bitumen ratios comparing to the other mixtures.
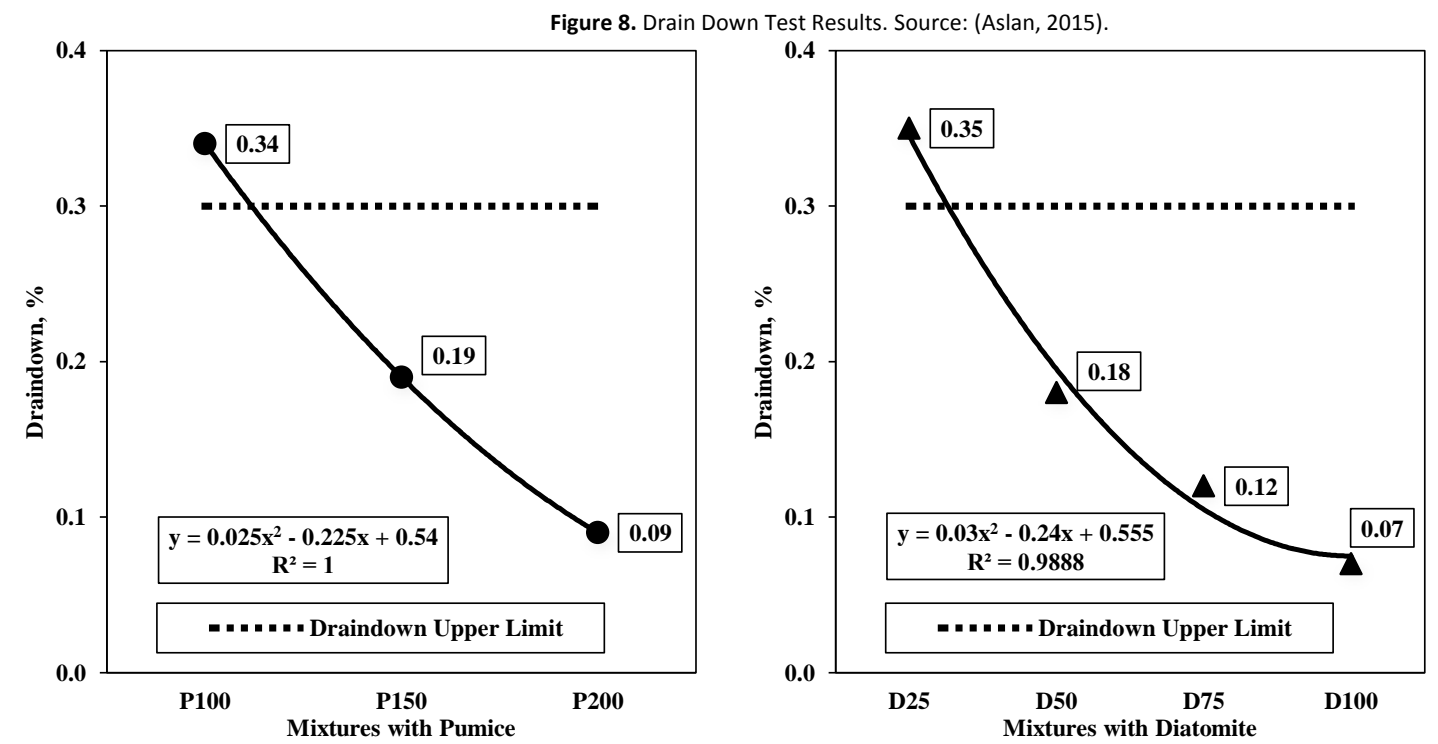

\section{Resistance to Moisture-Induced Damage Test Results}

This test determines the resistance of mixtures to moisture-induced damage (AASHTO T283-07, 2007). To be able to conduct this test, six Marshall samples are needed. Three of the samples are conditioned while the other three samples are waited in room conditions.

Mixtures with optimum bitumen ratio are prepared and cured at $60{ }^{\circ} \mathrm{C}$ for 16 hours. The next step is to compact the mixtures. After the compaction, the air voids must be between $6.5 \%$ and $7.5 \%$ (AASHTO T283-07, 2007). In this study, 12 blows were applied on both sides and the air voids were around $7.0 \%$.

Three of the six samples are conditioned with vacuum saturation. After the saturation ratio is in between $70 \%$ and $80 \%$, $10 \mathrm{~mL}$ of water is added to the samples. Then, the samples are placed in the refrigerator at - $18^{\circ} \mathrm{C}$ for 16 hours. After the freeze cycle, the samples are placed in a water bath at $60^{\circ} \mathrm{C}$ for 24 hours to conduct the thaw cycle. Finally, the freeze-thaw cycle is concluded (AASHTO T283-07, 2007).

In order to observe the Tensile Strength Ratio (TSR), all of the conditioned and unconditioned samples are maintained at $25{ }^{\circ} \mathrm{C}$ for 2 hours before the test. Loading is applied along the direction of the diameter, with the constant speed of $50.8 \mathrm{~mm} / \mathrm{min}$ until the vertical crack occurs. The TSR value is the ratio of the average value of the conditioned samples to the average value of the unconditioned samples (AASHTO T283-07, 2007). According to the specification, if the TSR 
ratio of a mixture is more than $80 \%$, it can be concluded that the mixture has a satisfying resistance to moisture-induced damage (Turkey General Directorate of Highways, 2013).

P150 and D50 mixtures having acceptable drain down values are also tested to see whether the TSR values are more than the minimum limit of $80 \%$. In Figure 9, it is seen that P150 and D50 mixtures have satisfactory TSR ratios of $80.4 \%$ and $92.2 \%$ respectively.

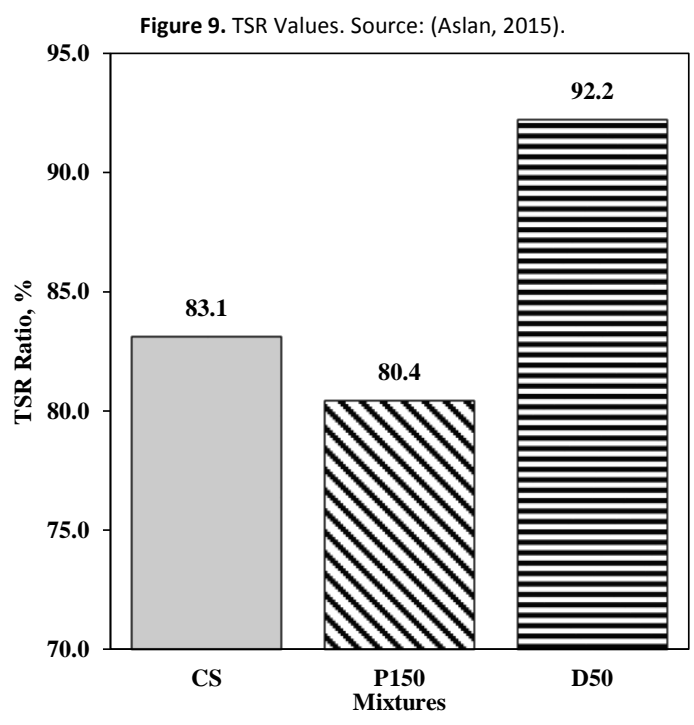

Conclusions

The purpose of this study was to investigate the possible use of pumice and diatomite as stabilizers in SMA mixtures. Extensive laboratory experiments were conducted to examine the aspects of SMA mixtures with different amounts of pumice and diatomite. According to the laboratory test results, the following outcomes are achieved:

- Optimum bitumen content, $\mathrm{V}_{f}, \mathrm{VMA}$ and flow values generally increase as the amount of pumice and diatomite increases. All of the mixtures produced with pumice (P100, P150, P200) have lower optimum bitumen content comparing to control samples. Mixtures produced with diatomite have higher bitumen content than the control sample except for D25 mixture. Almost all of the mixtures have fewer flow values if compared to the control sample. The only mixture having more flow value than the control sample is the mixture of D100.

- In most cases, an increase in the amount of pumice and diatomite results decrease in the stability and bulk specific gravity $\left(D_{p}\right)$. The stability values of P100, P150 and P200 are not more than the control sample. D25 and D50 mixtures have better stability values than control samples; however, D75 and D100 mixtures yield lower values in terms of stability.

- A certain amount of pumice and diatomite additions to the SMA mixtures prevents drain down of bitumen or bitumen/filler. The drain down values of P100 and D25 are not less than the maximum limit of $0.3 \%$. For this reason, using less amount of pumice and diatomite do not satisfy the specification. An increase in the amount of pumice and diatomite causes better drain down characteristics; nonetheless, it results in higher optimum bitumen content ratios for SMA samples.

- Samples of P150 and D50 have satisfactory resistances to moisture-induced damage. P150 mixture has a lower resistance to moisture-induced damage comparing to control samples. However, it can be recognized that the use of diatomite results in a better resistance to moisture-induced damage.

- According to the results of this study, the suitable content ranges can be provided. This study recommends that the minimum contents of diatomite and pumice are $0.5 \%$ and $1.5 \%$ respectively. However, the specific maximum contents must be selected by considering the other factors such as availability, workability, cost considerations and field conditions etc.

- In conclusion, the study has proved that there is a high potential of using pumice and diatomite in SMA mixtures as stabilizers. It should be also considered that other factors such as fatigue performance, rutting performance, environmental effect etc. are needed to be investigated. These factors have not been sought in this study but can be tested in future researches. 
This study was supported by the Scientific Research Projects Coordination Department of Erciyes University (Project Number: FBA-2015-5890). The authors of this paper are thankful to ERÜ/BAP for providing financial support for the development of this analysis.

References

AASHTO T283-07. (2007). Standard method of compacted hot mix asphalt (HMA) to moisture-induced damage. American Association of State Highway and Transportation Officials, Washington, DC (Vol. 283).

Arshad, A. K., Mansor, S., Shafie, E., \& Hashim, W. (2016). Performance of stone mastic asphalt mix using selected fibres. Jurnal Teknologi, 78(7-2), 99-103.

Aslan, S. (2015). The Investigation of Industrial and Natural Waste Materials in Hot Mix Asphalt. Erciyes University.

ASTM C131/C131M-14. (2006). Standard Test Method for Resistance to Degradation of Small-Size Coarse Aggregate by Abrasion and Impact in the Los Angeles Machine. West Conshohocken, PA, USA.

ASTM C88/C88M-18. (2018). Standard Test Method for Soundness of Aggregates by Use of Sodium Sulfate or Magnesium Sulfate. West Conshohocken, PA, USA.

ASTM D 4791. (2010). Standard Test Method for Flat and Elongated Particles in Coarse Aggregates. West Conshohocken, PA, USA.

ASTM D 854-14. (2014). Standard Test Methods for Specific Gravity of Soil Solids by Water Pycnometer. West Conshohocken, PA, USA.

Atasaral, M., Gungor, A. G., Orhan, F., Kasak, S., \& Cubuk, M. K. (2008). The use of diatomite in the stone mastic asphalt mixture. In Proceedings of the 4th Eurasphalt and Eurobitume Congress Held May 2008, Copenhagen, Denmark.

British Standards Institution. (2017). BS EN 12697-18: Bituminous mixtures. Test methods. Binder drainage. London, UK.

Herráiz, T. R., Herráiz, J. I. R., Domingo, L. M., \& Domingo, F. C. (2016). Posidonia oceanica used as a new natural fibre to enhance the performance of asphalt mixtures. Construction and Building Materials, 102, 601-612.

Huang, Y. H. (2003). Pavement Analysis and Design. Pearson Prentice Hall. Upper Saddle River, NJ, USA.

Kofteci, S. (2018). Investigation on the usability of pumice as mineral fibre in stone mastic asphalt. Journal of the Croatian Association of Civil Engineers, 70(08), 695-701.

Oda, S., Leomar Fernandes, J., \& Ildefonso, J. S. (2012). Analysis of use of natural fibers and asphalt rubber binder in discontinuous asphalt mixtures. Construction and Building Materials, 26(1), 13-20.

Pourtahmasb, M. S., \& Karim, M. R. (2014). Performance Evaluation of Stone Mastic Asphalt and Hot Mix Asphalt Mixtures Containing Recycled Concrete Aggregate. Advances in Materials Science and Engineering, 2014, 1-12.

Putman, B. J., \& Amirkhanian, S. N. (2004). Utilization of waste fibers in stone matrix asphalt mixtures. Resources, Conservation and Recycling, 42(3), 265-274.

Sharma, V., \& Goyal, S. (2006). Comparative study of performance of natural fibres and crumb rubber modified stone matrix asphalt mixtures. Canadian Journal of Civil Engineering, 33(2), 134-139.

Turkey General Directorate of Highways. (2013). Highways technical specification. Ankara, Turkey.

Vega-Zamanillo, A., Calzada-Pérez, M. A., Lastra-González, P., Indacoechea-Vega, I., \& Fernández Ortega, J. A. (2017). Analysis of the use of cupola furnace slags, green sand and reclaimed asphalt pavement in asphalt concrete mixtures for low intensity traffic. Revista de La Construcción, 16(2), 229-237. 